\title{
PROFIT LIMITATION CONTROLS PRIOR TO THE PRESENT WAR
}

\author{
H. Struve Hensel, * Lt. Richard G. McClung, U. S. N. R†
}

In the Bethlehem Steel Corporation ${ }^{1}$ case, Mr. Justice Black concluded the majority opinion of the Supreme Court with the following remarks:

"The problem of war profits is not new. In this country, every war we have engaged in has provided opportunities for profiteering and they have been too often scandalously seized. *** To meet this recurrent evil, Congress has at times taken various measures. It has authorized price fixing. It has placed a fixed limit on profits, or has recaptured high profits through taxation. It has expressly reserved for the Government the right to cancel contracts after they have been made. Pursuant to Congressional authority, the Government has requisitioned existing production facilities or itself built and operated new ones to provide needed war materials. It may be that one or some or all of these measures should be utilized more comprehensively, or that still other measures must be devised. But if the Executive is in need of additional laws by which to protect the nation against war profiteering, the Constitution has given to Congress, not to this Court, the power to make them."

In general, definitive Governmental steps to effectuate a limitation of munitions profits have awaited the outbreak of a war. ${ }^{2}$ No real effort was made in this country to impose systematic restrictions upon the profits of manufacturers of munitions prior to World War I. Furthermore, with the exception of several statutes limiting the price to be paid for armor plate, enacted in the Spanish-American War, all efforts to limit war profits prior to I9I7 were initiated by the Executive arm of the Government. Congress evidenced considerable interest in the prices of war matériel during the previous wars, but in the main its activities were limited to investigation and criticism. In the years between World War I and the present war, the Congress devoted a great deal of attention to the matter of limiting war profits and made a number of reports on the previous experience with war profit limitation attempts which could today be studied with a great deal of profit. Nothing definitive, however, was enacted prior to this war.

- A.B. r922, Princeton University, LL.B. I925, Columbia University. Member of the New York and District of Columbia Bars. Chief of the Procurement Legal Division of the Office of the Under Secretary of the Navy.

$\uparrow$ A.B. I935, Princeton University, LL.B. r939, Yale University. Member of the New York Bar. Member of the Procurement Legal Division of the Office of the Under Secretary of the Navy.

${ }^{2}$ See United States v. Bethlehem Steel Corp., 315 U. S. 289, 309 (1942).

${ }^{9}$ See Encrc. Soc. Scrences, articles on Profiteering (I934), Munitions Industry (1933). 


\section{Objectives of War Profits Limitations}

Before discussing the various attempts to control war profits undertaken by the Federal Government prior to this war, it is necessary to try to eliminate some of the confusion necessarily inherent in the objectives of price limitations and the objectives of profit limitations. Price limitations may involve profit limitations but not necessarily. Price limitations are devoted to an economic problem, i.e., keeping war costs at a minimum. Wartime profit limitations on munitions are directed primarily at a morale problem, i.e., the prevention of a slump in the nation's morale resulting from knowledge that war producers are enjoying what are generally and publicly recognized as excessive profits. We are all agreed that no one should become "rich" through a war.

"Morale" is an intangible substance, impossible to define precisely. Morale is largely a psychological matter. The armed forces and the taxpayers demand a forthright attempt on the part of the Government to prevent a few of the war contractors from making the war an unconsciously profitable venture for themselves. The difficulties in translating such desires into practical results lie in the fact that we are still relying on the profit motive as the main incentive for speedy, efficient and economical production. In an economy as complex as our national economy, and so long as the profit system remains the primary incentive to produce in time of war, there can be no absolute equalization of the burdens, or profits, of war. Our problem is, therefore, to maintain production with profit and morale without undue profit.

The imposition of price controls is almost always dictated by desires to minimize profits and yet too often fails to give full weight to the necessity of keeping the costs to the Government of procurement of munitions as low as possible in the light of all pertinent circumstances. This control of cost to the Government is logically a vastly more important matter than the limitation of profits to the contractor, yet that is not realized by the general public. Furthermore, price controls, dealing with all the elements of price, are difficult to establish. The Government in wartime must attempt in every way possible to encourage increased efficiency in production and the ensuing reduction in contractors' costs. Prices of munitions to the Government in wartime must be based, or perhaps, measured, ultimately upon cost of production. There is no other standard in wartime upon which to compute such prices. Producers should, of course, receive different rates of profits based upon the efficiency and skill with which they can reduce their costs of production. War procurement must also take into account many factors which affect cost-labor supply problems, maintenance of small businessmen, encouragement of inventions, and the like. Furthermore, the Government must acquire war supplies and weapons regardless of the cost to it or to the contractor.

The cost-plus form of contract has often been advanced as the only method of accurately determining the profits to the contractor; yet the cost-plus-a-percentage- 
of-cost contract induces waste and high costs and the cost-plus-a-detemined-dollarfee contract contains no incentives for reduced costs and minimizes the spur of the profit incentive. Profits should, theoretically, be a reward for performance and should be judged and compared in terms of relative performance.

In addition, profits are a relatively minor factor in the overall cost to the Government when munitions are being procured on the vast scale required for this war; a one per cent difference in profits would probably create more millionaires today than were created in the whole of World War I and have a small effect on our national economy. Government limitation of profits is also a major factor in minimizing inflation.

We are, indeed, faced with a dilemma and it is in this light that our previous failures to solve the problem should be judged.

\section{Atrearpts Prior to Worid War I}

In the early wars of this nation, contractors sold war materials to the Government at exorbitant prices. There are numerous public references during the Revolution to the excessive profits of suppliers and contractors, particularly in foodstuffs. ${ }^{3}$

The Continental Congress did evidence considerable interest in the costs of articles of war. For instance, the Naval Committee in 1775 recommended the construction of thirteen frigates as the backbone of the new American Navy and recommended further that the cost of these vessels, with two complete sets of sails, should not exceed $\$ 66,666$ on the average. On December $1_{3}$, r775, the Continental Congress appointed a committee, "with full powers to carry the above report into execution," and thus indicated its intent that the vessels authorized should be acquired within the cost estimated by the Naval Committee." As a matter of fact, the Revolution did summon into activity an immense range of legislative power over prices and profits. Most of this power was exercised by the states, for the Continental Congress constituted a government with limited authority over the loosely-knit federation of states. It was the legislation by the states during the Revolution, however, which laid the broad foundation for the legislative power of the national government in time of war. Thus we find that the Continental Congress on November 22, I777 recommended to certain of the state legislatures that they appoint "commissioners to regulate and ascertain the price of labour, manufactures, internal produce" and so forth. A month later the same body recommended "to the respective legislatures of the United States, forthwith to enact laws, appointing suitable persons to seize and take, for the use of the Continental Army of the said States, all woolen cloths, blankets, linens, shoes," and so on. In response to these resolutions, the state legislature did enact many laws fixing prices of labor and commodities, sometimes in the greatest detail. ${ }^{4}$ Typical of the attempts to control prices during

${ }^{3}$ Hearings before the Committee on Military Affairs on H. R. 3 and H. R. 5293, 74th Cong,, rst Sess. (r935) 590-598.

Journals of Congress 1774-1776 (Folwell ed. 1800 ) 272.

4R. Reuben Clark, Emergenct Legislation Passed Prior to December rgi7 (igr8) 21x, 212, $214-217,420,466,535,595$, etc. 
the Revolution was the law enacted by the State of New York in 1780 under which the profits of manufacturers, wages of mechanics and laborers, and prices of a long list of commodities were fixed at a figure "not to exceed twenty fold of the prices paid in r774." The latter date was chosen as reflecting normal conditions, and the twentyfold as measuring the debasement of the continental currency. This statute represented an effort to check inflation after it had occurred. ${ }^{5}$

Both the Army and the Navy were rather restricted by the parsimony of the Congress in the years between the Revolution and the Civil War. No real attempts were made to prevent profiteering in war supplies during this period, in part because so few supplies were being purchased.

The Civil War saw a vast increase in the purchases of war materiel, with largescale profiteering evident in the procurement of both the Army and the Navy. In the War Department, Secretary Stanton, after his appointment in 1862, made strenuous efforts to effect an improvement in the methods of Army purchasing. $\mathrm{He}$ established a commission to audit and adjust claims under contracts with the War Department and this commission in I862 and thereafter was successful in eliminating many excessive and fraudulent claims. ${ }^{6}$ The most publicized war contracts were those let by General Frémont, Commander of the Western Department, in the early part of the war. ${ }^{7}$ The Secretary of War appointed the Holt-Davis Commission to reconsider all of the contracts let under General Frémont's direction, and this Commission was instrumental in negotiating settlements at reduced prices with a large number of the contractors. ${ }^{8}$

Secretary of the Navy Gideon Welles met with similar difficulties in acquiring new vessels and supplies for the Navy during the Civil War. After unsatisfactory experiences with commission agents in the early months of the war, Welles in $186 \mathrm{r}$ appointed his brother-in-law, George D. Morgan, as the agent to make all purchases of vessels for the Navy. ${ }^{9}$ Morgan did an efficient job of buying vessels at much lower prices than the Navy had theretofore paid. The Secretary of the Navy was severely criticized for appointing a relative as the sole agent for the purchase of vessels, and the House Select Committee on Government Contracts submitted a resolution calling for the disapprobation by the House of Representatives of the practice. Even the Congress, however, was forced to admit that substantial savings had been effected by Morgan's purchases. ${ }^{10}$

${ }^{E}$ H. R. REP. No. 808, 75th Cong., Ist Sess. (1937) 3 (Report of the House Military Affairs Committee on H. R. 6704).

${ }^{6}$ Rep. Sec'y War (1862); cf. also Carl Sandburg, Abraham Lincoln, The War Years (1939), Vol. I, 423,440 .

${ }^{7}$ Frémont's purchases resulted in a number of actions in the courts. Reeside v. United Statcs, 2 Ct. Cl. I (I866), aff'd by a decision of the Supreme Court reported at $7 \mathrm{Ct}$. Cl. 82 (1868), gives a detailed picture of how Frémont operated in purchasing Army supplies. See also United States v. Morgan, 154 U. S. 565 (1869); United States v. Burton, 154 U. S. 566 (1869); United States v. Adams, 74 U. S. 463 (1868), reversing 2 Ct. Cl. 70 (I866); United States v. Mowry, 154 U. S. 564 (1869), reversing 2 Ct. Cl. 68 (1866).

${ }^{8}$ United States v. Adams, 74 U. S. 463 (1868).

- ReP. Sec'y Navy (I86i).

${ }^{10}$ See discussion on the report of the House Select Committee on Government Contracts, r3x Cono. 
All of the efforts at limitation of profits on Government contracts during the Civil War were undertaken by the Executive Departments, with, it is true, considerable prodding by the Congress. Many of the excesses in the prices paid for war munitions were the result of outright fraud upon the Government, and bribery of Government officials was by no means uncommon. Congress did enact various criminal statutes to prohibit certain of the fraudulent practices in connection with Government contracts. ${ }^{11}$

While the Civil War gave impetus for a time to large scale production of war munitions, no permanent munitions industry grew up in this nation, because the Army and Navy ordered almost nothing for some years after the war. It was not until the Government began to build the new Navy in the early eighties that important contracts for munitions were let to large manufacturers. ${ }^{12}$

In the development of plants in this country for the manufacture of heavy armor for the ships of the fleet, the Navy had paid prices for armor ranging between $\$ 574$ and $\$ 67 \mathrm{r}$ per ton. Feeling that such prices were unreasonable, the Congress enacted a statute approved March 3, 1897, limiting the average price to be paid by the Navy for armor to $\$ 300$ per ton. Several months thereafter another statute was passed authorizing the Secretary of the Navy, if he could not procure armor at $\$ 300$ per ton, to establish a public armor factory and to appoint a naval board to advise him on the subject. ${ }^{13}$ The armament manufacturers refused to manufacture armor at this price, and with the outbreak of the Spanish-American War in I898, Congress increased the authorized price to $\$ 400 .^{14}$ Contracts were let on this basis, but Congress by the Act of March 3, I899, again limited the price to $\$ 300$ per ton. ${ }^{15}$ Again the manufacturers refused to submit any bids except at prices per ton considerably in excess of this amount. ${ }^{16}$ Finally, by the Naval Appropriation Act, Igor, the Congress authorized the Secretary of the Navy to procure by contract armor "at a price which in his judgment is reasonable and equitable"; if the Secretary could not make satisfactory contracts for armor, he was authorized to erect a factory to produce heavy armor, and $\$ 4,000,000$ was appropriated for the purpose. ${ }^{17}$ The armor plant was never erected by the Navy.

Globe, Vol. 32, Pt. 4, 37th Cong., 2d Sess., Appendix, April 28, 1862, 124-130; Carr Sandburg, Abraham Lincoln, ThE War Years (I939), Vol. I, 426. For further consideration of both Army and Navy contracts, cf. the testimony and reports of the Committee on Government Contracts, 37th Cong. (1862), Vols. $x$ and $2 ;$ H. R. Exec. Doc. No. 65, 39th Cong., 2 d Sess. (I866-67).

${ }^{21}$ Cf. Act of July 16,1862 , I2 STAT. 577 ( 5862 ), with slight modification now 18 U. S. C. r940 ed, $\$ \S 199,202$; Act of July 17, 1862, I2 STAT. 594, 596 (1862).

${ }^{13}$ Harold and Margaret Sprout, The Rise of American Navat Power (1939) 165 et seq.; it Encyc. Soc. Sciences (I934) I28 (article, Munitions Industry).

13 C. O. Paullin, A Half Century of Naval Administration in America, i86i-igit, 40 United States Naval. Institute Proceedings (1914) I059, io6x; Act of March 3, I897, 29 Stat. 648, 665; Act of July $19,1897,30$ Stat. I05, I23; JoHN D. Long (Secretary of the Navy, 1897-I902), The New American Navi (I903), Vol. I, 46 et seq.

${ }^{14}$ Act of May 4, I898, 30 STAT. 369, 390. $\quad{ }^{15}$ Act of March 3, I899, 30 STAT. 1015, I045.

${ }^{16}$ LoNG, op. cit., supra note 13 at Vol. $I$, page 50.

${ }^{27}$ Act of June 7, 1900, 3I Stat. 684, 707; H. R. Doc. No. 95, 55th Cong., 2d Sess.; 31 Cong. Rec. 934 (1898), 32 Cong. Rec. 2rgo-2rg1 (I899); Report of the Chief of the Bureau of Ordnance, attached to REP. SEC'Y NAVY (I905), 45-47. 
The first attempt to limit profits by statute had thus threatened to cut off production of armor entirely. Profiteering in munitions and supplies was prevalent during the Spanish-American War, as in the Civil War. ${ }^{18}$ The effort to restrict war profits by setting a top price to be paid for munitions had been a complete failure. Though price-fixing was used to some extent in the first World War, no attempt was again made to attack the overall problem of war profits by establishing top prices for munitions.

The Government relied largely on competitive bidding as a means of limiting profits on all Government contracts prior to World War $I_{.}^{19}$ There have been recent investigations which indicate that the system of competitive bids did not perhaps achieve the lowest prices to the Government, ${ }^{20}$ but it is difficult to draw any just comparisons between Government purchases in peacetime and purchases in wartime. In peacetime there is generally a buyers' market for war materials, while in wartime the market clearly favors the sellers.

\section{Wordd War I Profit Limitation Atrempts}

The outbreak of World War I found the nation, as usual, without any program whatsoever for control of munitions prices or profits. True, the Congress had in 1916 passed an act imposing a tax of $121 / 2$ per cent on the profits of manufacturers of munitions, ${ }^{21}$ and on March 3 , x 917 , an act was approved providing for an excess profits tax of 8 per cent. ${ }^{22}$ Neither of these statutes was aimed primarily at limitation of profits on war contracts; the first was largely a reflection of the spirit of the times in reacting against traffic in munitions, and the second appears to have been primarily a revenue measure.

There were three primary types of attempted profit limitations during the first World War: (I) the use of cost-plus contracts, (2) price fixing and control, and (3) excess-profits taxes. The several Congressional committees which have investigated the matter of war profits in the last war have demonstrated quite conclusively that none of these methods accomplished effective limitation of profits or prices.

The first months of World War I were marked by the confusion and lack of planning in the procurement of war matériel. For a time, there was no central coordinating agency, and there was absolutely no program for mobilization of industry to produce for war. For a time the Army and Navy tried to continue their peacetime procurement methods of purchasing from the lowest bidder. In-

\footnotetext{
${ }^{18}$ Walter Millis, The Martial Spirit, a Study of Our Wat with Spain (1931) passim; Hearings before House Committee on Military Affairs on H. R. 3 and 5293, 74th Cong., Ist Sess. (I935) 590-598.

${ }^{10}$ The basic statute was Section 3709 of the Revised Statutes.

${ }^{20}$ Sen. Rep. No. 944, 74th Cong., Ist and 2d Sess. (Nye Committee, r935-1936); SEN. Rep. No. 480, Pt. 5, 77th Cong., 2d Sess. (Truman Committee, r942); H. R. Rep. No. 576, 77th Cong., 2d Sess. (House Naval Affairs Committee, January 20, 1942).

${ }^{21}$ Act of September 8, r916, 39 STAT. 756, 780.

${ }^{22}$ Act of March 3, I917, 39 STAT. rooo. Excess profits were defined as profits above 8 per cent of "actual capital" plus \$5000.
} 
deed, even after January, I9r8, many contracts made by the Army Quartermaster's. Corps were let on this basis. ${ }^{23}$ The initial stage of war procurement saw purchases being made on the old-fashioned bid basis, with the several Government agencies actually competing against each other in securing supplies. ${ }^{24}$ Some agencies therefore obtained excessive quantities of supplies while others did not obtain sufficient to meet their needs, and the prices of various war supplies were inflated because of the inflated demands of the several agencies. ${ }^{25}$ The President early established coordinating agencies to bring some order into Government procurement, starting with the Council of National Defense and ending with the War Industries Board in July, IgI7. ${ }^{26}$

\section{a. Cost-plus Contracts}

The competitive bid system, however, could not continue long during wartime. As prices of raw materials and labor rose rapidly, contractors refused to take fixedprice contracts. Accordingly, the cost-plus-a-percentage-of-cost contracts were devised and came into increasing use in the early part of the war. Thus, the Secretary of the Navy noted that shipbuilders refused to submit fixed-price bids for battle cruisers. ${ }^{27}$ The Supreme Court in the Bethlehem Steel Corporation case ${ }^{28}$ approvingly quoted the Igrg report of the Chief of the Construction Division, War Department:

Obviously no sane man would bid on a lump sum contract under such conditions, unless perchance he should treat the matter as a pure gamble and include an excessive margin in his proposal for unforeseen contingencies.

Cost-plus-a-percentage-of-cost contracts for a time supplanted all other forms of contracts for the larger purchases of the armed forces and the Emergency Fleet Corporation. Of more than $\$ I_{3} 750,000,000$ in contracts executed by the Army Ordnance Department up to the end of IgI7, the Chief of Ordnance testified that the great majority of these contracts were let on the cost-plus basis. ${ }^{29}$ As the cost-plusa-percentage-of-cost form of contract lent itself readily to abuse, the cost-plus-a-fixedfee contract was introduced and to some extent supplanted the other type of

${ }^{23}$ J. F. Croweli, Governarent War Contracts (1920) 2 I (Carnegie Endowment for International Peace, Preliminary Economic Studies of the War, No. 25).

36 Government Purchasing-An Economic Commentary, Temporary National Econome ComaIItTe Monograph No. I9 (76th Cong., 3d Sess., 1940), 43 et seq.; Graske, The Law of GovernMent Defense Contracts (r94I) 6-8.

${ }_{25}$ James R. Withrow, The Control of War Profits in the United States and Canada (1942) $9 \mathrm{I}$ U. of PA. L. REv. I94, 199.

${ }^{30}$ For the chronological sequence of unifying agencies, see TNEC Monograph No. x9, supra note 24, at 45 et seq.; Graske, op. cit., stpra note 24, at 8, 9, and Baruch, AMERican INDUstry in the War, Report of the War Industries Board to the President (I921), passim.

${ }^{27}$ Rep. SEc'y Navi (19I7) 30. The Naval Appropration Act of IgI6 (August 29, 1916, 39 STAT. 556) had provided that the Secretary might contract for such ships "on the basis of the actual cost plus a reasonable profit to be determined by him," and the major shipbuilders all submitted bids on a cost-plus-a-percentage-of-cost basis.

${ }_{28}$ See United States v. Bethlehem Steel Corp., 3I5 U. S. 289, 302 (I942).

${ }^{30}$ Hearings before the Select Committee on Expenditures in the War Department, Series $1, P t .5$, 66 th Cong., Ist Sess. (Igrg) 488. 
contract. $^{30}$ The difficulties of determining the "actual cost" under a cost-plus contract were just as great in I9I7 as they are today; in addition, there was the problem that under cost-plus-a-percentage-of-cost contracts, the contractors were tempted to increase their profits by increasing the cost. Apparently the Navy Department adopted as a basis for the determination of cost the principles set forth in the 1916 munitions profits tax act, ${ }^{31}$ but these principles were so general in terms as to furnish no guide at all. ${ }^{32}$ The interdepartmental conference of July, I9r7 on uniformity of contracts and cost accounting condemned the percentage-of-cost system and recommended instead the use of the cost-plus-a-fixed-fee type of contract. ${ }^{33}$

The cost-plus-a-fixed-fee contract was by no means the answer to all of the problems inherent in procuring war supplies at reasonable cost, with reasonable profits to the contractor. In World War I, as in the present war, the cost-plus-afixed-fee type of contract gave rise to many difficult administrative and accounting problems; in particular, the accurate determination of costs required a very large force of skilled auditors and accountants. ${ }^{34}$ Similarly, a desire to provide an incentive to reduce costs led to a modification of the cost-plus-a-fixed-fee contract in the form of a bonus added to the fixed fee for savings in actual cost as compared with estimated cost. It was in fact this type of contract which was before the Supreme Court in the Bethlehem Steel Corporation case and illustrated the tendencies such contracts have to encourage somewhat exaggerated estimates of cost.

The Army and the Navy made ostensible efforts to limit profits on the cost-plus contracts; both the War and Navy Departments included in a number of their contracts provisions specifying that profits thereon should be limited to to per cent of the actual cost. ${ }^{35}$ These limitations imposed in the contracts were not effective; and apparently no effort was made to recapture profits in excess of the specified percentages. Mr. Justice Black pointed out in his Bethlehem Steel Corporation opinion that any citation of the Io per cent figure as indicating average profits on cost-plus contracts during the first World War was "illusory" and "without basis in the realties of business experience." ${ }^{\text {"36 }}$ A report of the Federal Trade Commis-

\footnotetext{
${ }^{30}$ Charles E. Hughes, Report to the Attorney General on the Aircraft Industry (19i8) 134, reprinted as Appendix A, 57 Cong. Rec. 883, 906 (1918); H. R. Rep. No. 816, 66th Cong., 2d Sess. (I9r8) 49-53 (Expenditures in the War Department-Camps).

31 Act of September 8, 1916, 39 STAT. $756, \$ 302$.

${ }^{32}$ The Secretary of the Navy remarked that as "regards the determination of the actual cost, hardly any two accountants would agree exactly, this being a highly technical question involving a large number of factors." ReP. SEC'Y NAVY (Igr7) 3I. He further stated that the 1916 munitions tax act had been "found satisfactory in general" as a basis for cost determination, "although detail difficultics have naturally arisen."

33 TINC MONOGRAPH No. 19, supra note 24 , at 50.

${ }^{34}$ Cf. Hughes, supra note 30 , wherein he stated that "contracts of this sort lead to waste, foster abuses, and impose an almost intolerable burden of cost accounting, in itself a hindrance to rapid production," noted by Mr. Justice Black in the Bethlehem Steel Corp. opinion, 315 U. S. 289, 306.

${ }^{85}$ ReP. SEC'Y W'AR (rgI7) Vol. I, 28; id. (rgr8) Vol. I, 1319; id. (I919) 4138-42; Rep. SEc'Y NAvY (IgI7) 33; id. (Igr8) 685; id. (I920) I47-8.

${ }^{80}$ United States v. Bethlehem Steel Corp., 315 U. S. 289, 306-8 (1942).
} 
sion, made in I9I8 pursuant to Senate resolution, also makes it clear that profits on war contracts ran much above to per cent in several of the major industries. ${ }^{37}$

Mention should perhaps be made of the wide use of compulsory orders during World War I. Authority under the compulsory order statutes ${ }^{38}$ was often invoked to bring about purchases at reasonable prices when the prices quoted appeared too high. No stigma was attached to the issuance of a compulsory order in World War $\mathrm{I}$; in contrast, compulsory orders are rarely employed in the present war. ${ }^{30}$ In fact, the reduction of stipulated contract prices by means of the compulsory order might be termed a primitive method of renegotiation, although the analogy is not very apt. Nevertheless, the compulsory orders in World War I were employed to a limited extent in the light of total volume of procurement, and they were utilized in place of a contract, not to change prices under already executed contracts.

\section{b. Price-fixing}

At the same time that the Government agencies were attempting to maintain some form of control over profits under the several forms of cost-plus contracts, the General Munitions Board, and later the War Industries Board, approached the problem from the angle of fixing prices on certain commodities. Strangely enough, no statute authorizing over-all fixing of prices was enacted during the war. The War Industries Board derived such power to fix prices as it exercised from the power granted to the President to place compulsory orders with any manufacturer, ${ }^{40}$ and its derivative power to allocate priorities. ${ }^{41}$ The food and fuel control act of I $917^{42}$ gave the President very broad powers of control over prices of food and fuel products and through those powers the Food and Fuel Administration was able to exercise some authority over prices with statutory backing.

The War Industries Board established a Price Fixing Committee to fix prices for products other than foods and fuels; this Committee dealt almost exclusively with raw materials. ${ }^{43}$ The Committee was hampered in that it did not administer the prices it set, leaving this function to the commodity sections of the War Industries Board. Its general policy was to fix prices at fairly high levels, with the result that the low-cost producers in an industry made large profits. The Board justified

${ }^{37}$ Hearings before the Committee on Military Affairs on $H . R .3$ and 5293, 74th Cong., Ist Sess. (1935) 604 et seq. The report of the Federal Trade Commission (Taking THE Profits OUT OF WAR) is one of the exhibits, pages 604 et seq.

${ }^{38}$ National Defense Act of I9I6 (June 3, I9I6), 39 STAT. 213, 50 U. S. C. I940 ed. §80; Act of March 4, 19I7, 39 StAT. 213, 50 U. S. C. I940 ed. \$309; Act of June 15, 1917, 40 Stat. 182. Cf. REP. SEC'Y NAvY (19r7) 33 .

${ }^{30}$ Present authority is Section 9 of the Selective Training and Service Act of 1940, 54 Stat. 885, 892 , as amended, 50 U. S. C. I940 ed. $\$ 309$ (Appendix).

stupra note 38 .

${ }^{2}$ Abels, Price Control in War and Emergency (1942) go U. of PA. L. REv. 675, 682 et seq.

"Act of August Io, I917, 40 Stat. 276.

48 TNEC Monograph No. 19, supra note 24 , at 51, 52. The armed services were represented on the Price Fixing Committee, which was evidently very careful in performing its functions not to interfere with their procurement. Cf. ReP. SEC'y NAvy (x918) 98. 
this policy by the proposition that it was concerned first of all with stimulating production, and was forced to look after the less efficient producers in order to keep the full capacity of the industry in operation. It relied on the tax laws to recover much of the excessive profits.

Ostensibly, the Price Fixing Committee set prices by agreement with the industry concerned. Thus, Mr. Baruch, in his report to the President in I92x, remarked that the "bases in law for different regulations were varied, and in some cases doubtful," and emphasized the processes of negotiation by which the Government and industry arrived at prices. ${ }^{44}$ In point of fact, there was little about the agreements which was voluntary-they were entered into under thinly-veiled compulsion, the threat of commandeering. Mr. Baruch himself bluntly recognized this fact in later years, when he admitted that universal compliance with the price regulations was obtainable only with the aid of potential compulsion, and that "price-fixing by agreement" was as much of a euphemism as calling conscription "selective service" and referring to registrants for the draft as "mass volunteers."

The attempts of the War Industries Board to fix prices (limited, as heretofore noted, largely to raw materials) did not achieve very much in the way of limitation of profits. ${ }^{46}$ The Government in World War I ultimately relied almost entirely upon the excess-profits tax to eliminate excessive profits. It took the nation some little time, however, to come to this conclusion and to work out adequate tax laws.

\section{c. Excess-profits Taxes}

Mention has heretofore been made of the excess-profits tax imposed in March, I917. ${ }^{47}$ This statute was soon superseded by the War Revenue Act of $1917{ }^{48}$ which was retroactive for the period the March law was in effect, and applied to all business, whether carried on by individuals, partnerships, or corporations. The tax was computed on the net income in excess of a specifically defined normal return (the average rate of return of the business in the years I9II-rgr3), not to exceed Io per cent or be less than 7 per cent upon invested capital plus a specific credit. The rates of tax (varying from 20 per cent to 60 per cent) were graduated according to the amount by which the net income in excess of the designated normal return (rate) on invested capital exceeded specified percentages of the taxpayer's invested capital. The rate of tax on an individual or occupation "employing" no invested capital or not more than a nominal capital was a flat 8 per cent of the net income in excess of $\$ 6000$.

These taxes did not adequately get at the large scale profits enjoyed by the larger Government contractors. President Wilson in a message to Congress on May 27,

"BarUch, supra note 26, at 72 et seq.

${ }^{45}$ H. R. Doc. No. 163, 72d Cong., Ist Sess. (193x) 8I7 (Hearings Before War Policies Commission). The legal section of the War Industries Board on June 18 , $19 \times 8$, concluded that a threat to commandeer expressed in the form of a contract to induce the fixing of the price did not constitute duress. Abels, supra note $4 \mathrm{I}$, at 684 .

${ }^{2}$ Grosvenor B. Clatrson, Industrial Amertca in the World War (1923) 322; FTC repott, supra note 37 , passim.

${ }^{47}$ Supra note 22.

${ }^{48}$ Act of October 3, 1917, 40 StaT, 300. 
Igr8, indicated the need for a new tax bill to curb the profiteering which he noted was indisputable. ${ }^{49}$ Shortly thereafter, the Senate passed a resolution requiring the Secretary of the Treasury to submit information on war profits, specifically, to report all corporations which had earned over I5 per cent on their capital stock in I9I7, and the I916 profits of such corporations..$^{50}$ On June ro, 1918, another resolution was passed (both resolutions having been submitted by Senator Borah), directing the Federal Trade Commission to report on profiteering.51 The Commission's report was specific in indicating that profiteering existed in many lines. ${ }^{52}$ Pursuant to the earlier resolution, the Treasury Department's report was submitted on July 5 , Igr8; it showed high profit percentages and large salaries. ${ }^{53}$

After obtaining these factual studies, Congress finally enacted a tax law which in effect carried out President Wilson's program. ${ }^{54}$

The IgI8 law changed the coverage of the tax to include only corporations.55 The I9I8 law set up a new standard of normal income and added a war-profits tax to be paid to the extent that it exceeded the excess-profits tax. The war-profits tax was 80 per cent of the excess of the net income of the taxpayer over the warprofits credit, which consisted, roughly speaking, of an average of the income for the three pre-war years (I9II-I9I3) plus $\$ 3000$, with the further provision that the minimum war-profits credit should be ro per cent of the invested capital. The result of the application of this rather complicated formula, as was pointed out by the Nye Committee, ${ }^{56}$ was that corporations with meager pre-war incomes were assured of at least a to per cent return, free from the war-profits tax, but if they were fortunate enough to have a high rate of earnings before the war they were enabled to get an additional exemption. The 80 per cent rate of the war-profits tax was thus not imposed upon the entire profits of the corporation, but only upon the excess over the average pre-war income.

The Ig18 tax act retained the excess-profits tax as an alternative, to be paid if it was higher than the war-profits tax. The maximum excess-profits tax rate was 65 per cent, and the excess-profits credit was fixed at 8 per cent of the invested capital for the taxable year plus $\$ 3000$.

The excess-profits tax was retained after the war with reduced rates. The 80 per cent rate and the war-profits credit wiere abandoned, and the maximum excessprofits rate was dropped to 40 per cent for $19 \mathrm{~g} 9$ and rg20. While the rates were

${ }^{10} 56$ CoNg. Rec. 7115 (IgI8).

${ }^{50}$ Sen. Res. No. 253, 56 Cong. Rec. 7231 (1918) (65th Cong., 2d Sess.); id. at 7419 (I918).

E2 Sen. Res. No. 255, 56 Cong. Rec. 7558 (19r8) (65th Cong., 2d Sess.).

${ }^{2}$ Sen. Doc. No. 248, 56 Cong. Rec. 8458-62 (1918), also printed in Hearings before House Committee on Military Affairs on H. R. 3 and H. R. 5293, 74th Cong., Ist Sess. (1935) 604 et seq. Later the Commission made reports on profits in several industries, e.g. Cost Reports of the Federal Trade COMMIISTION-COPpER, June 30, rgrg.

${ }^{2} 3$ Sen. Doc. No. 259,56 Cong. Rec. 8671 (1918).

¿t Revenue Act of r9I8, 40 StaT. 1057 (approved February 24, 1919).

${ }^{65}$ The House Ways and Means Committee recommended this action because of the administrative difficulties in administering the excess profits tax as to individuals and because of the feeling that the heavy income surtaxes would render substantial justice between individual and corporate taxpayers.

${ }^{6}$ SEN. REP. No. 577 on H. R. 5529, 74th Cong., Ist Sess. (I935). 
thus reduced for the years after I9I8, the Revenue Acts did contain a provision designed to continue the application of the Igr8 war-profits tax rates to profits on war contracts entered into during the period April 6, r9I7, to November Ir, I9I8. Under the 1918 act the net income remaining after the deduction of the war-profits and excess-profits taxes was subjected to a normal corporation tax of 12 per cent for I9I8 and Io per cent for I9I9 and I920. The excess-profits tax expired in I92I.

The pivotal figure in the computation of the excess-profits tax was, of course, the computation of invested capital. Invested capital was made up on an historical or cost basis-it included cash paid in for shares, paid in or earned surplus and undivided profits (not including surplus and undivided profits earned during the year) but excluded borrowed capital and any assets (such as corporate shares) the income from which was not included in computing taxable profit. Assets were valued at original cost, revised by the depreciation or depletion allowed. If not acquired by purchase, they were taken at their actual cash value at the time of acquisition, but rigid limitations were imposed upon the value of good will and other intangible assets paid in for stock or shares. Any writing up of assets through revaluation, reorganization after March 3, I9I7, or otherwise was in general forbidden, and corporations which had written up their assets or reorganized before this date secured an enormous advantage thereby. It was extremely difficult to work out invested capital in a large number of cases, and there was a great deal of litigation on this issue. ${ }^{57}$

Mr. Baruch told the War Policies Commission that the World War excessprofits taxes could not capture profits due to price rises and, indeed, increased inflation because they took less than roo per cent of profits in excess of the normal return. ${ }^{58}$

As a revenue measure, the excess-profits tax appears to have been successful in World War I. Its yield became the largest source of revenue apart from borrowings; the average yield of the tax during the three-year period I9r7 to I9r9 was almost $\$ 2,000,000,000$, or more than one-fourth of the entire ordinary receipts of the Government. Apparently it was paid during the war without too much complaint or hardship, in part because of the enormous profits being made by Government contractors, and in part because of the relief provisions of the law and administrative regulations. The World War excess-profits tax was administered as a tax measure to bring needed funds into the Treasury. The Assistant Secretary of the Treasury estimated that taxes during the war absorbed about 70 per cent of

\footnotetext{
57 The Nye Committee points to the history of the Newport News Shipbuilding and Dry Dock Company's controversy with the Government on this subject. It took until I93I-I4 years-to settle the company's $19 x_{7}$ taxes because of the difficulties of determining invested capital, and then settlement was made by the Bureau of Internal Revenue only because it finally gave up and decided that it could not determine the company's invested capital but would make a special assessment. Under the assessment, the exemption was the same percentage of the company's net income as the average cxemption of representative concerns in the same or similar business was of the average net income of such concerns. Sen. ReP. No. 944, Pt. 2, 74th Cong., Ist Sess. (1935) 21.

${ }^{63}$ H. R. Doc. No. 163, 72d Cong., Ist Sess. (193I) 798 (Hearings before War Policies Commission).
} 
the increase of the average profits of the war years over the average profits for the years immediately before the war. ${ }^{59}$ The Nye Committee challenged these figures and calculated that only 44 per cent of the increase of war-years profits over pre-war profits was taken in taxes. ${ }^{60}$ Whichever percentage is taken, it is evident that there was a very wide margin for substantially increased profits arising out of the war. The controversies as to the taxes appeared to arise largely in the post-war years when the taxpayer might be confronted with additional claims for taxes, not contemplated during the war when he paid taxes, however patriotically, on the basis of his own returns.

After I9I9, as profits declined, the law was subjected to considerable attack and many taxpayers collected large refunds. In I920, Secretary of the Treasury Houston described the complexities of the income and profits taxes as "clogging the administrative machinery and threatening, indeed, its possible breakdown." Tax evasion and tax avoidance became far more prevalent after the war. ${ }^{61}$

The excessive administrative burden of the World War I excess-profits tax, the difficulties with invested capital determinations, the rigidity of the application of the tax, and its failure to reach a large segment of war profits, all indicate that the excess-profits tax, on the basis of such World War experience, is not alone sufficient to cope with the problem of war profits.

\section{Constberation of War Profit Limitations Between the Two Wars}

Following the first World War the Government returned to competitive bidding as the method for keeping profits down on Government contracts. This was the major safeguard until r940, although with the passage of the Vinson-Trammel Act in 1934 , Congress applied the percentage of cost limitation of profits formula to a substantial dollar volume of Government contracts. In I940, Congress turned again to the excess-profits tax as a means of attacking the limitation of profits on a general basis. The excess-profits tax, plus certain statutes limiting profits on cost-plus-afixed-fee contracts to specified percentages, constituted the main instrument of profit limitation up to the passage of the renegotiation statute on April 28, $1942 .{ }^{62}$

During the 23-year period between the armistice ending World War I and the outbreak of the present war, Congress considered approximately 200 bills and resolutions dealing, in one way or another, with the limitation of war profits. Of this number, less than one-fourth received serious consideration. No bill dealing with the entire problem of war profits became law. Certain statutes were enacted limiting profits to fixed percentages of price or cost of some munitions, but these statutes were peacetime measures, not designed to deal with war profits. The Second Revenue Act of I940, imposing an excess-profits tax, may be described as

${ }^{80}$ H. R. Doc. No. 163 , $72 \mathrm{~d}$ Cong., Ist Sess. (I93I) 689,690 (Statement of Arthur Ballantine to the War Policies Commission).

${ }^{\circ 0}$ Sen. Rep. No. 944, Pt. 2, 74th Cong., Ist Sess. (1935) 13-I5.

Q1 Id. at 44 et seq.

${ }^{62} 5$ STAT. 245, 4I U. S. C. A., note prec. §I (Supp. I942). 
an effort to limit profits on war contracts. Reliance was placed on the excess-profits tax in the period between October 8, I940 (date of approval of the Revenue Act) and the enactment of the renegotiation statute (April 28, 1942).

\section{a. $1919-1934$}

The investigations conducted during this period between the two wars indicated much criticism of and dissatisfaction with the attempts at profit limitation during World War I. It was not until r924 that Congress began to study certain bills designed to limit war profits. Meanwhile, some effort had been made to set up a planning agency to program more efficiently the mobilization of industry in the event of war. Because of the shockingly poor record of the Government in World War I in getting munitions to the actual theaters of combat, ${ }^{03}$ the immediate consideration for the armed services was the establishment of some overall program for the rapid transformation of industry to wartime production.

The National Defense Act of $1920^{64}$ was the first result of this pressure to increase the efficiency of wartime procurement and it directed the Assistant Secretary of War to make "adequate provision for the mobilization of material and industrial organizations essential to wartime needs." The War Department expended considerable effort in drawing up a program of industrial mobilization for war. ${ }^{65}$ While elements of the program were utilized as the nation prepared for the present war, it was never put into operation. By joint order of the Secretaries of War and the Navy, the Army-Navy Munitions Board was established in 1922 to coordinate procurement by the two services. ${ }^{66}$ All of these efforts were directed primarily at a more efficient and speedy method of wartime procurement; the planning did touch upon the prevention of war profits, but this essentially more difficult (though less important) problem was not emphasized.

The American Legion was instrumental in 1922 in having introduced in Congress the Capper-Johnson bill to deal with limitation of war profits. ${ }^{07}$ This bill was sweeping in its terms, and while efforts were made to secure favorable action upon it, the Congress did not consider it. ${ }^{68}$ At the same time, Representative John J. McSwain of South Carolina introduced a joint resolution to create a special Federal Commission to investigate the whole subject of war profits and to recommend

${ }^{63}$ TNEC Monograph No. I9, supra note 24 , at 53.

- 4 I Stat. 759, 764, 765 (r920).

${ }^{88}$ The Joint Board (established by a joint order of the Secretaries of War and of the Navy, dated July 17, rg03) established the Army-Navy Munitions Board by letter of June 27, 1922, approved by the Secretaries of War and of the Navy on June 29, 1922. By Executive Order 9024 of January 16, 1942, the Army-Navy Munitions Board was directed to report to the President through the Chairman of the War Production Board. By organization order of February 21, 1942, the Under Secretaries of W'ar and of the Navy established the membership of the Board as the Under Secretaries and a civilian chairman appointed by them.

${ }^{67}$ H. R. I320I, 67th Cong., 4th Sess., introduced December 6, 1922. The American Legion looms rather large in actively sponsoring or supporting many of the efforts to control war profits; it was instrumental in having a number of bills introduced in the middle 30 's.

${ }^{68}$ H. R. REP. No. 808 on H. R. 6704, 75th Cong., Ist Sess. (1937), a report of the House Military Affairs Committee. 
legislation. ${ }^{99}$ Both the Republican and Democratic party platforms in 1924 contained plans for the mobilization of industry in time of war and the control of profits to be realized from war production. The American Legion, among others, continued to press for favorable action in this matter, and finally in 1930, the McSwain Resolution, then known as the Wainwright-Snell Resolution, was passed. ${ }^{70}$

Prior to this time, however, the Congress had not given any very serious attention to the elimination of war profiteering. In I924 and in Ig28 the Committee on Military Affairs of the House of Representatives had held hearings on several comprehensive bills dealing with war mobilization and elimination of profiteering, but no action was taken on these bills. ${ }^{71}$

Thus, the attempt to come to grips with the lack of organization and confusion which characterized the first months of World War I culminated in the passage of a resolution which created a commission "to study and consider amending the constitution of the United States to provide that private property may be taken by Congress for public use without profit during war and methods of equalizing the burdens and to remove the profits of war, together with a study of policies to be pursued in event of war." The Joint Executive and Congressional Commission, the so-called War Policies Commission established pursuant to this resolution, conducted extensive hearings, brought out the inadequacies of the procurement procedures of World War I (particularly through the testimony of Mr. Bernard M. Baruch), and made several reports to Congress. ${ }^{72}$ Its recommendations were primarily concerned with setting up methods of speedy and orderly procurement. It endorsed the decision to abandon competitive bidding of war munitions in time of war. ${ }^{73}$ The War Policies Commission did enter the field of profit limitation in recommending that a constitutional amendment be passed to eliminate all doubts as to the power of Congress to prevent profiteering, and further, that in time of war individuals and corporations be taxed 95 per cent of all the income above the previous three years' average. ${ }^{74}$ There is no doubt that world-wide economic and political unrest spurred the Congress and the War Policies Commission to consider more carefully and intensively the procurement and economic problems attendant upon war. The Creditanstalt crashed in Vienna in I93I; Japan in the same year attacked Manchuria, and in I933 withdrew from the League of Nations.

In 1932, the Senate took up the recommendation of the War Policies Commission that a tax of 95 per cent of excess-profits tax be imposed in time of war, by passing Senate Resolution No. $180,{ }^{75}$ which referred such recommendation to the

${ }^{\circ 0}$ H. J. Res. 400, 67th Cong., 4th Sess., introduced December 6, I922.

${ }^{70}$ Pub. Res. No. 98, 7xst Cong., 2d Sess., approved June 27, 1930, 46 STAT. 825.

${ }^{71}$ House Committee on Military Affairs: Hearings on $H . R .484 I, H . R .811 I, H$. $J$. Res. 128,68 th Cong., Ist Sess. (March II, 13, 20, I924); Hearings on H. R. 455, H. R. 8313,H. R. 8379, 7oth Cong., Ist Sess. (1928). Cf. also, before Senate Military Affairs Committee, Hearings on $S$. 1620, 69th Cong., ist Sess. (1926); Sen. J. Res. 20, 7Ist Cong., Ist Sess. (r929).

${ }^{73}$ Rep. War Policies Comm., H. R. Doc. No. 163 , 72nd Cong., ist Sess. (I93I); id. H. R. Doc. No. 264, 72nd Cong., Ist Sess. (I932).

${ }^{73}$ H. R. Doc. No. 163, 72nd Cong., Ist Sess. (193I) 363.

rt H. R. Doc. No. 264, 72nd Cong., Ist Sess. (1932).

${ }^{75}$ Adopted March 8, I932, 72nd Cong., Ist Sess. 
Secretary of the Treasury for his comments and opinions. The response of the Secretary of the Treasury indicated that he did not believe enactment of such a tax would solve the problem. ${ }^{78} \mathrm{He}$ began by pointing out that the "ideal war-income tax would bring into the Treasury the entire amount of profits due to the war." The Secretary reviewed the World War I experience with excess-profits taxes and concluded that on the basis of such experience the suggestion to tax 95 per cent of all income above the three-year average prior to the war was unworkable. Portions of the excess profits, he noted, were in the form of inventories and improvements or additions to factories; a five per cent margin was too small a safety factor in view of the inevitable inaccuracies in calculating profits; invested capital as a basis for measuring the excess of income was very unsatisfactory and "should not be used again except as a last resort"; and the suggested rate might work great hardships in the case of individuals and encourage the payment of excessive salaries by corporations.

\section{b. The limitation of the Vinson-Trammel Act}

Following the reports of the War Policies Commission and of the Secretary of the Treasury with respect to the Commission's excess-profits tax recommendation, a number of bills and resolutions dealing rather generally with profit limitation were introduced. The request in 1934 that the Congress appropriate funds to build up the Navy to its treaty strength was the occasion for a spirited discussion in the Congress as to the limitation of profits on munitions and led ultimately to the incorporation in the Vinson-Trammel Act, authorizing the expansion of the Navy, of a flat percentage limitation of profits. ${ }^{77}$ The proposal to build up the Navy brought forth a considerable amount of criticism. ${ }^{78}$ The whole matter of the excessive profits enjoyed in the first World War was brought very much to the fore, and the Congress, which had in the years following World War I done little except authorize one major investigation, finally resolved to take some steps to limit profits. Shortly after H. R. 6604, the Vinson-Trammel bill, became law (March 27, 1934), the Senate debated and passed a resolution authorizing Senator Nyc to begin his investigations of the munitions industry. ${ }^{79}$

Section 3 of the Act to establish the Composition of the Navy (the VinsonTrammel Act) provided that the Secretary of the Navy should not make contracts for the vessels therein authorized unless the contractor agreed to pay into the Treasury all profit, as determined by the Treasury Department, in excess of 1o

\footnotetext{
${ }^{76}$ SEN. Doc. No. 105, 72nd Cong., Ist Sess. (1932) (Letter from the Secretary of the Trcasury in response to S. Res. No. I80).

${ }^{77} 48$ STAT. 505 (1934), 34 U. S. C. 1940 ed. $\$ 496$.

${ }^{78}$ The President had authorized the use of some $\$ 238,000,000$ of P.W.A. funds for building ships for the Navy, and the subsequent request by the Secretary of the Navy for additional funds aroused a general discussion of naval policy and of profits on naval shipbuilding. 78 CoNG. REC. 1586 et seq., I60r (1934). Senator Borah delivered his "Take the Profits out of War" speech. 78 Cong. Rec. 3688 et seq. (1934).

${ }^{72}$ SEN. RES. No. 206, 73rd Cong., 2d Sess., adopted April I2, I934.
} 
per cent of the total contract price. Any subdivision of a Navy contract or subcontract $^{80}$ thereunder involving an amount in excess of $\$ 10,000$ was to be subject to the conditions to which the prime contractor agreed. The Act further provided that, if the excess profit were not voluntarily paid, the Secretary of the Treasury might collect it by the methods usually employed for collecting income taxes. ${ }^{81}$ The contractor was to make available for inspection and audit all books and records. The method of ascertaining the amount of excess profit was to be determined by the Secretary of the Treasury in agreement with the Secretary of the Navy; ${ }^{82}$ credit was to be made for Federal income taxes paid or to be paid on the amount of such excess profit. ${ }^{83}$

As the method of percentage profit limitation was the only method put into operation by Congress for the period r934-I940, the chronological discussion of the various proposals for limiting profits is interrupted to give a brief résumé of the Vinson-Trammel type of limitation during that period. By the Act of June 25, 1936, the Vinson-Trammel Act was amended to make it somewhat more flexible. ${ }^{84}$ This amendment provided that the Io per cent limitation should be applied to the total contract prices of all contracts made during the taxable year; thus, losses on some contracts could be offset against excess profits on others. Also provision was made allowing net losses on contracts for the preceding taxable year to be deducted in determining net profits for the current taxable year.

When Congress determined to build up the merchant marine, it incorporated in the Merchant Marine Act of 1936 the ro per cent limitation of the VinsonTrammel Act as to contracts for the construction of merchant ships by the Maritime Commission. ${ }^{85}$ The Merchant Marine Act added certain directions as to computing costs and excess profit. No salary of more than $\$ 25,000$ per year was to be considered a part of the cost of building a ship in computing excess profit; ${ }^{86}$ furthermore, the Maritime Commission was directed to scrutinize construction

${ }^{80}$ In Aluminum Co. of America v. Commr. of Internal Revenue, 47 B. T. A. 543 (I942), the Board of Tax Appeals narrowly construed the word "subcontract" appearing in the stante. The case is pending on appeal to the Circuit Court of Appeals for the Third Circuit.

81 The Revenue Act of 1939, approved February I0, 1939, specified that the Secretary of the Treasury should collect excess profits not voluntarily paid as required by the Vinson-Trammel Act and that all provisions of the Revenue Act of $1934,48 \mathrm{STat}$. $68_{3}$ (1934), including penalties, were to be applicable. 53 STAT. II2 (I939), 26 U. S. C. I940 ed. $\$ \$ 650,651$.

S3 The first joint order determining the method of ascertaining the amount of excess profit was T. D. 4434 issued in May, I934. This was amended by T. D. 4723 (January 6, I937) and T. D. 486r (September 19, I938). T. D. 5000 was promulgated August 15, 1940, and thus was applicable only for 2 months. Until April, 1942, however, T. D. 5000 was applied as the basis for determining reimbursable costs under most Army and Navy cost-plus-a-fixed-fee contracts; it is still used today, by the Army particularly, and for some Navy contracts.

${ }^{83}$ Cf. Section 3806 of the Internal Revenue Code, added by the Revenue Act of 1942, 56 STAT. 798, 26 U. S. C. A. $\$ 3806$ (Supp. 1942), with respect to renegatiation.

8449 STAT. I926 (1936), 34 U. S. C. I940 ed. $\$ 496$.

so 49 STAT. I985, I998 (I936) \$505, 46 U. S. C. I940 ed. \$II55.

${ }^{80} \mathrm{Cf}$. par. 45 of Explanation of Principles for Determination of Costs Under Governatent Conrrscrs, put out by the War and Navy Departments in April, 1942; this paragraph also provides for a top limit of $\$ 25,000$ on salaries as allowable cost under a Government contract. 
costs and overhead expenses to determine whether they were "fair, just, and not in excess of a reasonable market price." ${ }^{187}$

The Act of April 3, I939 ${ }^{88}$ first extended the percentage profit limitation to cover Army aircraft contracts. The Vinson-Trammel Act was further amended to provide that the Io per cent of the contract price limitation applied only to naval vessels, and that I2 per cent was to be allowed on contracts for military or naval aircraft. This statute also specified that a net loss or deficiency in profit, due to failure to earn the permitted $\mathrm{I} 2$ per cent in any taxable year, might be deducted during the next four taxable years in determining the excess profits. Also, in this same month of April, I939, the Secretary of the Navy was authorized to enter into defense construction contracts on a cost-plus-a-fixed-fee basis, with the fee limited to to per cent of the cost of the contract exclusive of the fixed fee. ${ }^{80}$

Public Law. No. 671, 76th Congress, approved June 28, I940 (the Navy "SpeedUp" Act), ${ }^{90}$ completed the experimentation with the Vinson-Trammel Act. This Act changed the percentages to define excess profit as that in excess of 8 per cent of the total contract prices completed within a taxable year, or 8.7 per cent of the total cost of performing such contracts, whichever was the lower, and to limit the application of the Act to contracts in which the award exceeded $\$ 25,000$ (\$10,000 previously). ${ }^{91}$ It may be said that all of these statutes establishing percentage limitations (with the possible exception of the last) were straight peacetime measures, not designed to deal with profits of contractors under a full wartime procurement program.

On September 9, I940, the profit limitation provisions of the Vinson-Trammel Act, as amended, were limited to contracts for the construction of naval vessels. ${ }^{02}$ With enactment of the Second Revenue Act of I940 (October 8, 1940), the Congress attempted to attack the problem of profits generally on munitions contracts by means of the excess-profits tax, ${ }^{93}$ and accordingly it suspended the profit limitation statutes applicable to all Army and Navy and to most Maritime Commission contracts and subcontracts, entered into after December 3I, 1939, or uncompleted on that date by contractors and subcontractors subject to the excess-profits tax imposed by Title II of the Revenue Act. ${ }^{94}$

The Vinson-Trammel Act and its amendments must be written off as a failure,

${ }^{87}$ See regulations by the Maritime Commission under Merchant Marine Act, Prenrnce-Halz, GovERNMENT CONTRACTS, par. 22, 987.

${ }^{88} 53$ STAT. 555,560 (I939) \$14, 34 U. S. C. I940 ed. $\$ 496$.

80 Act of April 25, r939, 53 STAт. 590, 59 r.

${ }^{80} 54$ STAT. 676, 677 (1940), 4r U. S. C. r940 ed., note prec. §r.

${ }^{21}$ Regulations were prepared jointly by the War, Navy and Treasury Departments: T. D. 4906, 4909 and 5000 (June 23, 1939, June 28, r939, August 15, 1940).

${ }^{22} 54$ STAT. 875,883 (I940), 4 T U. S. C. 1940 ed. note prec. \$I.

${ }^{03}$ H. R. REP. No. 2894, 76th Cong., 3d Sess. (August 29, 1940), a report of the House Ways and Means Committee on H. R. Io4r3.

${ }^{26}$ The Treasury Regulations on limitation of profits were suspended. Cf. T. D. 5034 (r94I). T. D. 5000, however, is still used by the Navy Department in determining allowable costs under some cost-plus-a-fixed-fee contracts. The Vinson-Trammel Act provisions may be revived by proclamation of the President or joint resolution of Congress. 
even in peacetime, in accomplishing any effective profits control. According to a statement of the Treasury Department, the net amount assessed under the Act on contracts for Navy vessels and aircraft up to August 3r, I942, was roughly $\$ 7,450,000$, and on Army aircraft contracts for the same period, $\$ 70,000 .^{95}$ As plans for vastly increased procurement of war munitions were made after the fall of France in I940, it was established that the Vinson-Trammel Act limitations were making shipbuilders and aircraft manufacturers reluctant to enter into contracts and were definitely delaying the war program. ${ }^{96}$ Investigations of profits on the contracts of the armed forces, after suspension of the Vinson-Trammel Act, have quite conclusively established that the Act was ineffectual to prevent very large profits to certain contractors. ${ }^{97}$

\section{c. Investigations and Discussion, 1934-r940}

During this period I934 to I940, when the percentage profit limitation statutes were in force, the Congress did consider a number of other methods for eliminating excessive profits of war contractors. The Nye Committee's reports constituted perhaps the most exhaustive investigation of war profits limitations; the Committee was extremely critical of the ineffectiveness of the World War I attempts to limit profits, and seriously considered nationalizing the American munitions industry. ${ }^{98}$ The Congress was conscious of war profits during this period as it had never been before. Again its activities should be viewed in the perspective of international events-in 1935 Mussolini marched into Ethiopia; in I936 Spain became embroiled in civil war; and in I937 Japan began to wage "active" war against China and Hitler started the series of moves which led to Munich and the outbreak of European war. Despite the publicity surrounding the Nye Committee hearings and the vast amount of literature to the effect that the munitions-makers had pushed the nation into World War I, the Congress was not unaware of the possibility that the nation might be drawn into some future war. Certainly there had never been so much study before any other war in our history as to the most efficacious war mobilization and control of the war economy.

On March 2, 1934, about a month before the Nye Committee was established, the House had passed House Resolution No. 275 (73d Congress), authorizing the House Military Affairs Committee to investigate alleged profiteering on Government contracts, particularly Army aircraft contracts. The preamble to this resolution as originally introduced indicated that it was passed in part because there

\footnotetext{
${ }^{\circ 5}$ Statement by the Treasury Department submitted by Senator Walsh, Hearings before a Subcommittee of the Senate Finance Committee on Section 403 of Public Law 528, 77th Cong., 2d Sess. (September 29 and 30,1942$) 96$.

${ }^{D B}$ See debate on the I940 excess-profits tax bill, 86 Cong. Rec. II, 243 (August 29, I940).

${ }^{\circ} \mathrm{Cf}$. Sen. Rep. No. 480, Pt. 5, 77th Cong., 2d Sess. (January 15, 1942) 87 (Truman Committee); H. R. Rep. No. I634, 77th Cong,, 2 d Sess. (January 20, I942), a report of the House Naval Affairs Committee pursuant to H. Res. No. 162 .

${ }^{08}$ Sen. Rep. No. 944, Pts. 4, 5 and 7, 74th Cong., 2d Sess. (1936). See S. 2603, 75th Cong., Ist Sess., introduced by Senator Nye on June 8, 1937, providing that the Secretaries of War and of the Navy should acquire facilities to supply all war munitions.
} 
were "a number of bills pending before the Committee on Military Affairs of utmost importance to the problem of national defense in general, and to the operations of the War Department."99

\section{H. R. 5529, 74th Congress (1935)-American Legion Bill}

H. R. 5529, 74th Congress, introduced by Representative McSwain of South Carolina February 7, I935, apparently was the first comprehensive bill to mobilize production in time of war and to take the excessive profits out of war production which was extensively considered by both Houses. ${ }^{100}$ Title I of this bill comprised a complete revenue act for wartime purposes. As passed by the House of Representatives on April II, I935, section 8 of Title I provided that "upon the declaration of war there shall be imposed a tax of roo per centum of all excess profits that may be earned during said period of war as defined in this Act." After passage by the House the bill was referred successively to the Nye Committee, the Senate Military Affairs Committee and the Senate Finance Committee, all of which held hearings and made reports upon the bill. The Nye Committee concluded that H. R. 5529, as approved by the House, relied primarily upon price-fixing to control profits, and recommended that a comprehensive excess-profits tax be adopted as the most useful weapon to limit war profits. ${ }^{101}$ The Nye Committee, it is true, also considered the excess-profits tax as vital for producing revenues to finance the war. After the bill had been very drastically revised by the three Senate Committees, it was allowed to lapse in the Senate.

Meanwhile, the House in January, r935, had held hearings on two bills approaching the limitation of profits as a part of a broad scheme of economic mobilization in time of war; these hearings are instructive in bringing out some of the shortcomings of World War I attempts. ${ }^{102}$ These two bills were never reported out by the House Committee, apparently because other bills covering the same subject matter were receiving major consideration at the time.

\footnotetext{
${ }^{89}$ The preamble was stricken when the resolution was adopted, 78 Cong. Rec. 3622 (1934). This resolution was prompted in large part by the accidents which occurred following the take over of the air-mail routes by the Army. See 78 Cong. REc. 3613-3622 (1934). The authority granted the Committee by this resolution was extended by H. R. Res. No. 59, 74th Cong., adopted January 18, 1935.

${ }^{100}$ This bill was sponsored by the American Legion, and also by Mr. Baruch. Cf. H. R. Rrp. No. 808 oN H. R. 6704, 75th Cong., Ist Sess. (1937) 2.

${ }^{101}$ SEN. ReP. No. 577, 74th Cong., Ist Sess. (May 3, 1935) (also printed with the report of the Senate Military Affairs Committee, SEN. ReP. No. 889, 74th Cong., Ist Sess., June 14, 1935). The Senate Military Affairs Committee considered primarily the industrial mobilization fcatures of the bill and recommended that the tax provisions be referred to the Senate Finance Committee. SEN. REp. No. 889, 74th Cong., Ist Sess.. (June I4, 1935). The Finance Committee considered the measure both as a means of eliminating excessive profits and as a means of providing revenues. SEN. REP. No. 2337, 74th Cong., 2d Scss. (June 10, 1936). It rewrote the tax provisions of H. R. 5529 almost entirely. The Finance Committee provided for amortization of war facilities, contrary to the recommendations of the Nye Committee. SEN. Rep. No. 2337, stipra, at 17.

${ }^{102}$ Hearings Before the Committee on Military Affairs on H. R. 3 and 5293, 74th Cong., 1st Sess. (I935) (Taking the Profits out of War).
} 


\section{War Department Industrial Mobilization bills (1935)}

The War Department had prepared industrial mobilization and draft bills which were to be submitted to Congress upon a declaration of war. These bills were introduced in the Senate without prejudice early in I935, in order to stir up discussion prior to the outbreak of any war. ${ }^{103}$ They were referred to the Nye Committee, which reported upon them on June 2, $1935 .{ }^{104}$ The Committee noted that the proposed legislation relied primarily on price-fixing and taxation "to check profiteering by industry in general and to eliminate the basic war evils of inequality and inflation"105 and warned that neither of these methods could provide an adequate answer to excessive war profits.

\section{Sheppard-May bill, Nye bill, and related bills (1937 and 1938)}

The next major consideration of the economic problems raised by war and of the elimination of excessive profits was the Sheppard-May bill, introduced in both houses on January 6 , $1937^{106}$

The Sheppard-May bill was sponsored by the American Legion and was also supported by Mr. Baruch and the Secretaries of War and the Navy. ${ }^{107}$ Section 9 of the Senate bill specified that upon the declaration of war "there shall be imposed a tax of 95 per centum of all income above the previous three-year average, with proper adjustments for capital expenditures for war purposes by existing or new industries." The Secretary of War made the following rather oblique comment about this provision $:^{108}$

"Section 9 imposes an excess-profits tax to be effective during the period of war. The War Department refrains from commenting on this section, believing that other agencies of the Government are better qualified and have more direct responsibilities in connection with taxation measures. It is desired to emphasize, however, that any tax measure adopted must not remove the incentive to produce, and thus threaten the more vital activity of securing the munitions required in war."

Both the Secretary of War and the Secretary of the Navy suggested a number of amendments to the bill. The Secretary of the Navy stated in his letter to the Committee: $:^{109}$

${ }^{103}$ War Department bills S. 1716-S. 1722, 74th Cong., Ist Sess.

${ }^{204}$ Sen. ReP. No. 944, Pt. 4, 74th Cong., 2d Sess. (x935).

${ }^{105}$ Id. at 33. The approach of the War Department to profit limitation in these bills was much the same as that of the War Policies Commission. Cf. H. R. Doc, No. 27r, 72nd Cong., Ist Sess. (I932).

${ }^{100}$ S. 25, 75th Cong., Ist Sess.; H. R. I954, 75th Cong., Ist Sess., the companion bill, was introduced by Representative Hill of Alabama on the same date. Nothing was done with H. R. 1954 by the House Committee on Military Affairs, and Representative May of Kentucky reintroduced substantially the same bill, as H. R. 9604, 75th Cong., 3d Sess., on February 24, 1938. A somewhat similar bill, also sponsored by the American Legion (H. R. 6704, 75th Cong., Ist Sess.), was introduced by Representative Hill on April 27, 1937, and this bill was reported out by the Committee on May 12, I937 (H. R. Rep. No. 808, 75th Cong., Ist Sess.). H. R. 6704 in its tax provisions was very similar to the later May bill (H. R. 9604). Mr. Baruch supported all of these bills, and made some rather extravagant claims for H. R. 6704 (see H. R. REP. No. 808, 75th Cong., Ist Sess. (1937) 5).

${ }^{107}$ See Sen. Rep. No. 480 , 75th Cong., ist Sess. (1937) 2 et seq. (Comm. on Mil. Affairs).

${ }^{108}$ Id. at I5. 
"The current difficulties being experienced by all of the procurement agencies of the National Government due to the restrictive provisions of the Walsh-Healey Act (49 Stat. 2036) as regards the employment of labor, and the Vinson-Trammel Act (48 Stat. 505), as amended by the act of June 25, r936 (49 Stat. x926), restricting the profits of Government contractors seem to indicate the necessity for the removal of these restrictions to insure the smooth operation of the Government procurement services in time of national emergency.

"Tax provisions in any measure come solely within the purview of Congress, and, therefore, the only comment offered on section 9 is quoted from exhibit 1 of the first day's hearings before a subcommittee of the Committee on Military Affairs, United States Senate, Seventy-fourth Congress, first session, on H. R. 5529, May 25 and 3I, I935, 'that the tax provisions must not be of such a nature as to hinder the procurement of munitions when the necessity for their manufacture arises." "

Senators Nye and Lundeen of the Senate Military Affairs Committee submitted a minority report on the Sheppard-May bill, ${ }^{110}$ in which they stated that the bill represented a "very peculiar kind of bargain. It offers something for every shade of believer in what ought to be done in time of war." They criticized the excessprofits tax provisions, pointing out prophetically that our past history indicated that a period of several years of foreign war might elapse before our entry into it; that in such event there would be a substantial pre-war increase in prices and profits resulting from trade with the belligerents; and that to use the three years immediately preceding our entry into the war as the basis for determining excessive profits might result in the imposition of slight or no excess-profits taxes on many war contractors.

In fact, Senator Nye's views as to the proper type of war excess-profits type measure were embodied in S. I33r, introduced February 2, I937. ${ }^{111}$ Title I of this bill established a complete income tax act to supersede existing revenue acts in time of war. A tax of Ioo per cent would be levied on that portion of a corporation's net income in excess of 6 per cent of the adjusted declared value of its capital stock (thus attempting to avoid the alleged disadvantages of using either invested capital or the three-year income average prior to the declaration of war as a basis for computing excess-profits). ${ }^{112}$ The Senate did nothing with this bill, which presumably embodied the views of the Nye Committee, based on its investigations, as to the most efficacious methods of controlling war profits. ${ }^{118}$

${ }^{110} \mathrm{Id}$, at 20.

${ }^{112}$ 75th Cong., Ist Sess. (1937). Senators Clark (Mo.), Bone (Wash.), Vandenberg (Mich.) and Pope (Idaho) were also sponsors of this bill. At this same time, Senator Connally, then Chairman of the Senate Finance Committee, introduced a war tax bill-S. 1248, 75th Cong., Ist Sess., introduced February I, 1937. This bill prescribed a lower schedule of tax rates than the schedule provided in the Nye bill, and based its corporate tax upon a percentage of the undistributed net incomc. Senator Connally in I939 reintroduced substantially the same bill as S. 2160,76 th Cong., Ist Sess. (introduced on April r3, r939).

112 Various provisions were inserted in the bill to prevent undue deductions from gross income for salaries, selling costs, depreciation and depletion. Senator Nye's bill also gave the President wide powers in the field of economic control; Title III authorized him to fix prices, determine priorities, license business, and requisition materials; other titles of the bill vested very broad controls over industry in the President.

${ }^{118}$ Excess-profits tax bills containing features of the Nye bill were introduced in both I938 and 1939 
The House version of the Sheppard-May bill provided with respect to taxation of war profits that there should be in effect "a system of taxation which shall absorb all profits above a fair normal return to be fixed by Congress," and that the Secretary of the Treasury should make the studies required to formulate such a plan of taxation. The House Committee on Military Affairs did not report on the bill until March I, 1938. ${ }^{114}$ The Committee was of the opinion that roo per cent "of all profits shown to be due to war-time business conditions" should "be taxed out of the person, firm or corporation earning such excess profits," noting that this recommendation was in accord with the earlier recommendations of the War Policies Commissoin. ${ }^{115}$ The House bill (and, it must be granted, the Senate bill to a large extent) constituted merely a pious expression of hope as to eliminating excessive war profits, and offered no concrete means of effecting such elimination. ${ }^{116}$

Representative Maverick introduced on February 16,1938 a companion bill to Senator Nye's earlier bill. ${ }^{117}$ This bill contained only the tax provisions of the Nye bill and eliminated completely all of the industrial control provisions. Nothing was ever done with either bill.

The reappearance of the May bill and the introduction of the Maverick bill were occasioned by the President's message to the $75^{\text {th }}$ Congress on January 28, $193^{8},{ }^{118}$ in which he stated:

"I believe that the time has come for Congress to enact legislation aimed at the prevention of profiteering in time of war and the equalization of the burdens of possible war. Such legislation has been the subject for many years of full study in this and previous Congresses."

In response to the President's message, a number of new bills were introduced in the early months of 1938 dealing with the limitation of war profits, but none of those bills was considered by the Congressional Committees. ${ }^{119}$ The sole concrete

-S. 3912, 75th Cong., 3d Sess., introduced April 27, $193^{8}$ by Senator Bone and 26 other Senators; and S. 1885, 76th Cong., Ist Sess., introduced March 21, 1939, by Senator Bone and 49 other Senators. Twelve bills introduced in the House early in 1939 were identical with the latter Senate bill (S. 1885)H. R. $5176,5177,5183,5184,5230,5233,5234,5274,5290,5316,5317$, and 5360 (all introduced between March 21 and 25, 1939). Both the Secretaries of War and of the Navy recommended against enactment of S. 1885 largely on the basis of the drastic change in the economic structure of the country which would be caused by making such a sweeping statute effective upon the outbreak of war. The Secretary of War recommended that the whole subject of excess profits be studied by the Treasury Department and legislation thereon be drafted and revised in peacetime, ready for presentation to Congress in emergency. See the letter of the Secretary of War dated May 5, I939 and the letter of the Acting Secretary of the Navy dated June 7, 1939, 86 Cong. Rec. 8624, 8625 (1940). All of these bills, both Senate and House, were likewise tabled and forgotten.

${ }^{2 x 4}$ H. R. REp. No. 1870, 75th Cong., 3d Sess. (March $x, 1938$ ).

115 Id. at 3 .

${ }^{110}$ Note the caustic remarks contained in the minority House report, submitted by Representatives Maverick, Anderson and Kale, id. at 15 et seq.

${ }^{117}$ H. R. 9525, 75th Cong., 3d Sess. (1938). Senator Nye's bill, S. 1331, 75th Cong., Ist Sess. (1937), is discussed above.

${ }_{118} 83$ CoNG. REc. Ir88 (r938). To get the proper historical background it should also be noted that this message of the President called for an increased Navy.

${ }_{110}$ Note H. J. REs. 585, H. R. 939I, H. R. 9408, H. R. 9525 (the Maverick bill), H. R. 9604 (the May bill), S. 3912, and H. R. rogr2, 75th Cong., 3d Sess. 
result of this recommendation of the President was the passage of the Act of May I7, I938, amending the Vinson-Trammel Act and making it applicable to all contracts for the ships authorized for the increased Navy. ${ }^{120}$

\section{Adoption of Excess-Profits Tax Act (1940)}

In 1939 and I940, prior to enactment of the excess-profits tax, approximately $3^{\circ}$ bills were introduced dealing with limitation of war profits generally. As war was declared in Europe, and as war production mounted apace in this country, the Congress grew more and more insistent upon adoption of some form of excessprofits tax. With the consideration of the r940 National Defense Tax bill in May and June, I940, it was apparent that the Congress was going to pass some form of tax reaching profits on manufacture of munitions. Several amendments to the National Defense Tax bill ${ }^{121}$ (which became the Revenue Act of 1940 ) ${ }^{121^{a}}$ which amendments would have provided a comprehensive tax plan for wartime profits, were adopted by the Senate but were eliminated from the bill in conference. The House Ways and Means Committee had reported out the bill without any excessprofits tax provisions of general application, but had remarked in its report ${ }^{122}$ that it had carefully considered proposals "to provide special amortization for national defense industries and to provide for the imposition of excess-profits taxes," which it insisted should be considered together. It further noted that it had instructed its technical assistants and the Treasury officials to prepare legislation on these subjects which could be made applicable to the calendar year I940.

The Senate Finance Committee made some substantial changes in the bill, but added no new provisions. ${ }^{123}$ On June 19 , r940, when the bill was being debated on the Senate floor, Senator LaFollette offered as an amendment a new Title IV, providing for an excess-profits tax based on invested capital, with rates from 20 to 40 per cent of excess-profits. ${ }^{124}$ This amendment was based on the rg2I excessprofits tax (which was merely a modification of the Revenue Act of r9I8), and the experience of IgI7 to I920 with the excess-profits tax. ${ }^{125}$ Despite the arguments raised that the matter should be more carefully considered, the Senate approved the LaFollette amendment. ${ }^{126}$ Senator Bone then offered as an amendment another "War Profits Taxation Act," being in fact the old Nye bill of r935, ${ }^{127}$ which had been introduced and reintroduced a number of times. Senator Connally thereupon suggested as a substitute for Senator Bone's amendment, his own bill for excess-profits taxes, which was a direct lineal descendant of the earlier bills which

${ }^{120} \mathrm{Cf}$. discussion, supra in text to note 77 et seq.

121 H. R. 10039, 76th Cong., 3d Sess. (1940).

${ }^{121 a} 54$ STAT. 516, 26 U. S. C. I940 ed. $\$ \$ 12$ et seq.

${ }^{122}$ H. R. ReP. No. 2491, 76th Cong., 3d Sess. (June 10, 1940) 3.

${ }^{123}$ SEN. REP. No. 1856, 76th Cong., $3 d$ Sess. (June 15, 1940).

12486 Cong. Rec. 8594 (June I9, 1940). 12586 Cong. Rec. 8933 (June 22, 1940).

${ }^{128} 86$ Cong. REc. 8607 et seq., 8614 (June 19, 1940).

12786 Conc. REc. 8619 et seq. (June I9, 1940). Cf. S. 3912, 75th Cong., 3d Sess., introduced April 27, 1938, and S. 1885, 76th Cong., 1st Sess., introduced March 21, 1939. 
he had introduced. ${ }^{128}$ Senator Connally's amendment was adopted by the Senate; $;^{120}$ thus the bill as approved by the Senate contained two complete excess-profits tax measures. Both amendments were stricken in conference, ${ }^{130}$ with the understanding that the matter of excess-profits taxes would be studied intensively and that action would be taken in the near future.

Shortly after approval of the Revenue Act of I940, the President addressed a brief message to Congress as follows: $:^{131}$

"We are engaged in a great national effort to build up our national defenses to meet any and every potential attack....

"It is our duty to see that the burden is equitably distributed according to ability to pay, so that a few do not gain from the sacrifices of the many.

"I, therefore, recommend to the Congress the enactment of a steeply graduated excessprofits tax, to be applied to all individuals and all corporate organizations without discrimination."

H. R. I04I3, the excess-profits tax, bill, was introduced by Mr. Doughton on August 27, I940. This bill dealt with three related features: (I) suspension of the profit limitations under the Vinson-Trammel Act; ${ }^{132}$ (2) the provision of amortization for defense facilities; and (3) an excess-profits tax. The House bill was a rather complicated bill which allowed excess-profits to be measured by either of two methods: average income for the base period I936-I939, or percentage of income for the base period to invested capital for the base period, ${ }^{133}$ with certain discriminations for corporations using the former method. The Senate Finance Committee attempted to simplify the House bill, and changed it very substantially. ${ }^{134}$ The Senate Committee believed that the House bill, which was favored by the Treasury, was primarily a revenue raising bill rather than a prohibition of excessive war profits. ${ }^{135}$ The Senate bill seems to have been drafted with the idea that it achieved the "average-earnings" method of computing excess-profits, rather than the "invested-capital" theory. The bill as finally adopted by both houses was an extremely complicated measure which partook of both theories, ${ }^{136}$ and clearly

${ }^{228}$ S. 1248, 75th Cong., Ist Sess., introduced February I, I937; S. 2160, 76th Cong., Ist Sess., introduced April 13, I939; cf. 86 CoNG. REc. 8624, 8626 (1940).

13086 CoNG. REc. 8630 (June I9, I940).

${ }^{130}$ H. R. REP. No. 2697 , 76th Cong., 3d Sess. (June 2r, r940), a Conference Report on H. R. roo39. The bill was enacted into the Internal Revenue Code, 54 STAT. 516, 26 U. S. C. 1940 ed. \$\$I2 et seq. ${ }_{131}$ H. R. Doc. No. 854, 76th Cong., 3d Sess. (July I, I940), 86 Cong. Rec. 9 I27 (1940).

${ }^{132}$ Mr. Vinson stated on the floor of the House that the defense program was being delayed because of failure to suspend these provisions and to enact some excess-profits tax upon which contractors could rely. 86 Conc. Rec. II243 (August 29, 1940).

${ }_{133}$ H. R. REP. No. 2894, 76th Cong., 3d Sess. (August 29, I940), a report of the Ways and Means Committee.

${ }^{134}$ Sen. REP. No. 2114, 76th Cong., 3d Sess. (September II, r940). Senator LaFollette submitted a minority report castigating the Senate bill and recommending that his own amendment to the earlier I940 bill be adopted.

${ }_{185} 86$ Cong. REc. r2057 et seq. (September I3, I940).

${ }^{130}$ H. R. Rep. No. 3002, 76th Cong., 3d Sess. (September 30, 1940), a Conference Report on H. R. 10413, which was enacted into the Excess Profits Tax Act of 1940 (October 8, 1940), 54 STAT. 974, 975 ff., 26 U. S. C. 1940 ed. $\$ \$ 710$ ff. 
represented an uneasy compromise. ${ }^{137}$ The excess-profits tax statute was amended by the Excess-Profits Tax Amendments of $194 \mathrm{I},{ }^{188}$ and by the Revenue Act of I942. ${ }^{139}$ The rates are now 90 per cent of adjusted excess-profits net income, as defined in the Act, or 80 per cent of the corporation surtax net income, whichever is the lesser, with a post-war refund of ro per cent of the tax. ${ }^{140}$ Even after enactment of the excess-profits tax statute, Congress did not rely entirely on this method of getting at profits. It retained in effect a number of statutes limiting the fees on cost-plus-a-fixed-fee contracts, and enacted a number of additional statutes limiting the fees on certain cost-plus contracts to specified percentages of the estimated cost. ${ }^{141}$ The excess-profits tax as enacted and amended was in large part designed as a revenue measure.

The renegotiation statute adopted April 27, I942, was aimed at the achievement of better prices to the Government in the procurement of munitions and the elimination of excessive war profits by means of more accurate pricing to the Government. Since the enactment of the renegotiation statute, there have been a number of movements in Congress to repeal the statute entirely and to rely upon the excess-profits tax for the elimination of war profits.

\section{The Efficacy of Wartime Profit Limitation}

The preceding chronological survey of profit limitation attempts prior to this war indicates some fairly obvious conclusions. First and foremost of all, it must be emphasized that prices and profits are not the primary consideration upon the outbreak of war. As the Under Secretary of War has recently stated in testifying as to renegotiation and alternative methods of controlling excessive war profits, the armed forces "are more interested in getting the goods than anything else."142

13786 CoNG. REc. 12922 , 12923 (October $\mathrm{r}, \mathrm{I940}$ ).

${ }^{238} 55$ STAT. I7 (I94I), incorporated into Internal Revenue Code, 26 U. S. C. \$710 (Supp. I94I).

${ }^{139} 56$ Stat. 798, Act of October 2I, 1942, Pub. L. 753, 77th Cong., 2d Sess.

${ }^{140} \mathrm{Id}$. at $\$ \$ 202,250,26$ U. S. C. A. 710(a)(r), 780 (Supp. 1942).

${ }^{211}$ Cf. 54 STAT. 872, 873, Io U. S. C. 1940 ed. \$1 336 a (Army contracts for military posts); 54 StAT. 965,968 , 10 U. S. C. I940 ed. $\$ 1336 \mathrm{a}$ (Army contracts for military posts); 55 STAT. 49, 53 (March 23, I94I) (Navy public works contracts); 55 STAT. I5I, I68 (May 6, 194I) (Navy construction contracts); 55 STAT. 262 (June 24, 194 $\mathrm{Y}$ ) (Navy public works contracts); 55 STAT. 366, 375 (Junc 30, I94I) (Army contracts for military posts); 55 STAT. 592, 593 (July 14, 1941) (Navy public works contracts) 55 STAT.; 658, 664 (August 21, 1941) (Navy public works contracts); 55 STAT. 669, 679, 68I (August 25, I94I) (Navy public works contracts, Marine Commission contracts); 55 STAT. 745, 753 (October 28, I94I) (Navy public works contracts); 55 STAT. 810, 815 (December 17, 194I) (Navy public works contracts); 55 STAт. 176, I78 (March 27, I942) (Army and Navy contracts); 56 Stat. 314, 316 (June 5, I942) (Army contracts for military posts); 56 STaT. 6r1, 632 (July 2, I942) (Army contracts for purchase of land); Pub. L. 92, 78th Cong. (June 26, 1943) (Navy contracts for purchase of land). In addition certain statutes limiting profits to a fixed percentage remaincd in effect after passage of the excess-profits tax-note particularly 54 STAT. 676, 4 I U. S. C. I940 ed. prec. \$I (Navy cost-plus-a-fixed-fee contracts). Also paragraph 7 of Title II of Execunve Onder No. 900r, dated December 27, I94I, and promulgated under the First War Powers Act, I941, approved December I8, I941, 55 STAT. 838, 50 U. S. C. \$601 (Supp. I94I, Appendix), provides that in the absence of other applicable profit limitation statutes, the fixed-fee under any cost-plus-a-fixed-fee contract executed under the War Powers Act should be limited to 7 per cent of the estimated cost.

${ }_{142}$ Hearings before a subcommittee of the Senate Finance Committee on Section 403 of Pub. L. 528 , 77th Cong, 2d Sess. (September 29 and 30, 1942) I4. 
The nation must obtain large quantities of a very wide variety of munitions and war supplies as rapidly as possible. So long as the nation maintains its present form of economy based upon the profit motive, it will be necessary in many cases to pay high prices to obtain these munitions and supplies. Mr. Baruch in a letter to the Nye Committee succinctly stated the elementary truth of the matter: $:^{143}$

"Much as it may be decried, the cold fact remains that ours is an economy motivated by profits. A certain return on money is necessary to make our industrial system work. ... Much was said at the hearing about this being a new war psychology.... Our whole industrial system is a complex massive machine built and geared to run on investment and profit. There is no proof that it will run on psychology and there is much that it will not. Certainly we should not select an hour when the enemy is at the gates to find out whether it will or not. ... Money will not invest and run the extreme risks of war production for a fraction of 3 per cent."

Exactly the same point is made by the Secretaries of War and of the Navy in their comments upon the excess-profits tax bills in 1937. ${ }^{144}$ The reports of the War Policies Commission emphasized that the nation would have to do vastly better in the way of getting munitions to the battle fronts than it had done in I9I7 and I9I8, and that while prices and profits would have to be carefully watched, they were of distinctly secondary importance.

There have been, in the main, three major types of attempts to limit profits on munitions contracts-specific percentage limitations on costs, price fixing and control, and taxation.

The limitation of profits to specific percentages has never worked well. The cost-plus-a-percentage-of-cost contracts constituted the first step along this line, and the experience with those contracts indicated that the Government would never again return to them. The Vinson-Trammel Act type of limitation in reality reduces all contracts thereunder to cost-plus-a-percentage-of-cost contracts, though the controls are somewhat more clearly established. The Nye Committee's report indicated that the Vinson-Trammel Act was not achieving its purposes; ${ }^{145}$ the Committee stated that it found "from wartime experience, enough evidence of the difficulty of auditing thousands of old vouchers and of properly allocating the overhead which the companies may have improperly saddled on to Navy vessels, to declare that there is no effective profit limitation law today."146 Later investigations have proven that this type of limitation did not prevent excessive profits even in peacetime. ${ }^{147}$ Similarly, as the defense program was stepped up so substantially in 1940, there were indications that the Vinson-Trammel legislation was definitely impeding the placement of war contracts. This type of profit limitation has another very serious drawback in that, in the words of the Nye Committee,

${ }^{143}$ Sen. Rep. No. 944, Pt. 2, 74th Cong., Ist Sess. (I935) (letter dated April 12, 1935, page II, note Io).

244 Supra notes 108 and 109.

${ }^{145}$ SEN. REP. No. 944, Pt. I, 74th Cong., Ist Sess. (1935) 323 et seq.

${ }^{116}$ Sen. Rep. No. 944, Pt. 7, 74th Cong., 2d Sess. (1936) I2.

147 Supra notes 94 and 96 . 
"there is absolutely no effective control of costs possible without a huge policing system of auditors and inspectors constantly on the premises."148 It is not to be denied, of course, that cost-plus-a-fixed-fee contracts have a very necessary place in the overall picture of war procurement, especially in its early phases when manufacturers are turning to products with which they are utterly unfamiliar. This proposition again, however, emphasizes the fundamental premise that the assurance of a reasonable profit to the contractors in order to get necessary supplies immediately, outweighs the consideration of more efficient methods of limiting profits.

Turning next to price controls, the limited experience of the Spanish-American War and the attempt during the early months of the first World War to use pricefixing as the main method of eliminating excessive profits in munitions manufacture has indicated the ineffectuality of this method. In World War I, in order to obtain the necessary production by marginal producers, prices were set at a high enough level to insure a profit to high cost manufacturers. The establishment of a single price for both low and high cost producers resulted, however, in tremendous profits for the former. ${ }^{149}$ If different prices are set for different producers so that each will receive his cost of production plus a reasonable profit, the net result is that each producer has a cost-plus contract. In addition, the problems of enforcement of price regulations are enormous. General MacArthur, then Chief of Staff, told the War Policies Commission that evasion was inevitable if prices of munitions were set at peacetime levels, and that "in the end the Government's efforts would probably be largely gesture."150 The personnel selected to administer price control and having the essential experience are inevitably either drawn from the industries over which they are to exercise control, or must be guided by the advice of businessmen from that industry. World War I experience proved that there will undoubtedly be a favorable attitude to industry in fixing the price levels. Robert R. Brookings, Chairman of the World War Price Fixing Committee, frankly told representatives of the nickel industry: $:^{151}$

"We are not in an attitude of envying you your profits; we are more in the attitude of justifying them if we can. That is the way we approach these things."

Finally, experience with excess-profits taxation in the World War I and prior to this war has not been such as to indicate that this method satisfactorily limits war profits. ${ }^{152}$ The difficulties of working out a satisfactory formula which will eliminate the profits attributable to war and leave the necessary incentives to produce are almost insuperable. The chief stumbling block heretofore has been the determination of a valuation base upon which to determine the percentage of allowable return. The difficulties of fixing valuations of railroads and public utilities are analogous to the problems which the tax authorities faced in World

${ }^{148}$ SeN. REP. No. 944, Pt. 4, 74th Cong., 2 d Sess. (1936) 324.

${ }^{160}$ Sen. Rep. No. 944, Pt. 2, 74th Cong., ist Sess. (1935) 56 et seq.

${ }^{150}$ H. R. Doc. No. I63, 72nd Cong., ist Sess. (I93I) 372.

${ }^{151}$ Sen. ReP. No. 944, Pt. 2, 74th Cong., Ist Sess. (I935) 5.

${ }^{152}$ Note particularly Sen. Rep. No. 480, 75th Cong., Ist Sess. (1937); SEN. Rep. No. 944, Pt. 2, 74th Cong., Ist Sess. (r935). 
War I in applying the invested capital base. ${ }^{163}$ The burden placed upon the authorities charged with the administration of an excess-profits tax act are vast indeed, especially in the light of the necessary discretion which must be placed in such authorities in administering such act.

The case for the excess-profits tax as the primary means of limiting war profits has recently been presented to the House Ways and Means Committee. ${ }^{154}$ The reasons most cogently urged on behalf of the excess-profits tax are the fact that it allows the contractor to know or to estimate accurately what his net profits on war production will be, and that it is a stabilizing factor in presenting a standard for determining excessive profits. These arguments misplace the emphasis entirely; the essential purpose of profit limitation in wartime must be the achievement of more accurate and reasonable prices to the Government and, while certainty is desirable, it must always be sacrificed to the broader interests of the Government.

The Truman Committee early this year investigated the administration of the renegotiation statute. Its report succinctly stated the reasons why the attempts at profit limitation prior to this war had never been successful.: ${ }^{155}$

"(I) Because of the wartime need for rapid procurement of materials of war, new materials with which there has been no previous manufacturing experience and other articles previously manufactured only in relatively small quantities, some procedure for subsequent price adjustment is necessary and desirable if excessive war profits and costs are to be avoided.

"(2) Taxes alone will not do the job because (a) higher corporate tax rates are likely to encourage higher costs and discourage economical production; (b) no scheme of taxation has been devised which is sufficiently flexible to provide an incentive for efficient low-cost production; (c) a profit percentage which would fairly reward one war contractor with a different financial setup, and would provide inordinately excessive profits for a third contractor with a still different financial problem.

"(3) War contractors in most cases can protect themselves against loss by escalator clauses and other contract provisions for contingencies. The people can obtain protection in many cases only through some procedure such as renegotiation.

"(4) Experience has shown 'cost-plus' contracts to be worse than worthless in the effort to prevent excessive costs. They strongly tend to increase costs instead of the reverse."

It seems extremely unlikely that any legislation can have more than moderate success in eliminating all profits arising solely out of war or in equalizing the burdens of war. War tax measures appear to have achieved a good deal in the way of raising revenues; experience thus far has indicated that they can do little to eliminate the abnormal profits arising from war. The advocates of the excessprofits tax have no answer to the proposition that it is necessary to have flexibility in working out equitable limitations of war profits, and the excess-profits tax

\footnotetext{
${ }^{203}$ Sen. REP. No. 944, Pt. 2, 74th Cong., Ist Sess. (I935) 25 et seq., discusses some of the technical difficulties inherent in applying different measures of capital value.

IVt Hearings before the House Ways and Means Committee on H. R. 2324, H. R. 2698 and H. R. 3015,78 th Cong., Ist Sess. (September, I943).

${ }^{165}$ Additional Report of the Senate Special Committee Investigating the National Defense Program pursuant to SEN. Res. 7I, 77th Cong., on Renegotiation of War Contracts, Sen. Rep. No. 10, Pt. 5, 78th Cong., Ist Sess. (March 30, I943) 2.
} 
achieves a rigid uniformity which experience has plainly shown is not adequate to achieve reasonable prices of munitions to the Government. The excess-profits tax does achieve some degree of certainty for contractors, but the price of such certainty is the ineffective rigidity which so hampers the Government.

All efforts at war profit limitation involve attempts to achieve as much saving as possible to the Government in the way of making munitions prices reasonable in the light of the speed in procurement required. Such efforts have also sought to preserve the continued efficacy of the profit motive to induce extraordinary war production and industrial effort. So long as the nation's war production is premised on the profit motive, industries engaged in war work will and should make "reasonable" profits, which will presumably exceed the profits of industries not so engaged. All efforts at profit limitation prior to this war have been faced with two major problems-first, the determination of what are "reasonable" profits or prices to the Government, or, stating it obversely, the determination of a proper standard for defining excessive profits, and second, the discovery of effective means to prevent profits from exceeding such standard. No general rules have as yet successfully been laid down for solving these two excessively complicated problems as applied to all cases. "Reasonable" is a rather imprecise word when applied to war profits, as in any other connotation, and attempts to define it meet the problem of using other rather broad and indefinite terms. Reasonable war profits are those which will encourage the contractor to efficient war production and yet will not make the prices of munitions unfair to the Government. Reasonable profits are those which, when judged by the general standards and mores of the day, are acceptable to the majority of the citizens of the nation.

Consider for a moment the difficulties inherent in establishing a standard. War contracts vary widely in substance and form. Airplanes purchased for $\$ 100,000,000$ can be produced more rapidly than a battleship costing the same amount. Reasonable profits under a contract involving $\$ 100,000,000$ to be performed within one year with a minimum capital investment may be quite different from reasonable profits to be allowed on a contract requiring the same amount of money but to be completed over a period of three or more years and requiring a larger permanent investment. In determining what profits are excessive, it is also necessary to consider the varying treatments fairly to be accorded contractors whose plant facilities and working capital are supplied by the Government and to contractors supplying plant and working capital in addition to management.

The effect of increased volume and the experience which goes with it must also be studied. It is often difficult to make allowance for such factors in advance. Costs and profits seemingly reasonable at the start of the contract often become unreasonable after volume and experience have increased. Furthermore, it is necessary to consider to what extent the procurement agencies are to offer rewards for increased speed and efficiency. High costs can be more expensive than high profits. While there must be some review or limitation of the amount of the reward for 
speed and efficiency, there is no doubt that the force of the profit motive must not be unduly restricted, at least until some equally compelling substitute is found.

Turning to the second part of the problem of devising equitable methods for limiting war profits, and assuming that a standard of reasonable profits has been devised to fit all cases and accurately weigh all relevant factors-an untenable assumption in the light of our past experience-it may be doubted whether a universal rule should be laid down which will require a return to the Government of all profits above that standard. Consideration must always be given to the desirability of offering the contractor a chance of increased profits in return for increased efficiency and production; such increased profits may be very small and continuously diminish. England in the early months of the war collected through excess-profits taxes all profits above a certain standard established for each taxpayer by reference to profits in pre-war years. After a trial, England apparently concluded that the absolute limitation of profits should be modified, and provided for an unconditional return after the war of 20 per cent of the war excess-profits tax. Thus the spur of an ever increasing profit, no matter how small, has been preserved.

The intricacy of our economic organization and the dependence, particularly in time of war, of prime contractors upon subcontractors, raise their own peculiar problems in the establishment and administration of any standard of reasonable profits. The skilled personnel and detailed work required to administer any form of profit limitation have already been touched upon.

The war profit limitation attempts prior to the present war have demonstrated conclusively that there is no categorical answer to the matter of elimination of war profits and prices of munitions. Experience in this war might indicate that there is no reasonably satisfactory answer to be had to the problem so long as we operate with the profit motive as the primary incentive for wartime production. The nation entered World War I entirely unequipped to cope with either the production problems or the economic problems facing it. The nation entered this war far better prepared to meet the incredibly complex production problems incident to the war. Notwithstanding, however, the great amount of effort expended in the I930's in the investigation and consideration of various methods of wartime profits controls, the country was hardly better equipped to meet the problems of munitions prices and profits on December 7, I94I, than it was on April 6, I9I7. This is not to suggest that the exhaustive investigations of war profits during this period did not serve a purpose; indeed, they served a very useful purpose in pointing out the shortcomings of our previous efforts at war profit limitation and lighting up the major problems to be faced in formulating a control over munitions prices. Again, it is possible to suggest that there is no answer to our failure to be prepared to handle this problem efficiently and expeditiously upon the outbreak of war. Having balanced the equities, the nation has concluded that the incentive of the profit motive, with its obvious attendant difficulties as to profit limitations, is to be preferred to a system based upon some other theory, under which perhaps complete control over return upon capital could be established. 